\title{
Peran Perbankan Dalam Pencegahan Dan Pemberantasan Tindak Pidana Pencucian Uang Yang Dilakukan Oleh Nasabah
}

\section{The Role of Banking in The Prevention and Eradication of Money Laundering Crimes Conducted by The Customer}

\author{
Pronika Juliantika Manihuruk*, Triono Eddy \& Ahmad Fauzi
}

Program Studi Magister Ilmu Hukum, Universitas Muhammadiyah Sumatera Utara, Indonesia

Diterima: 22 Juli 2020; Direview: 29 Juli 2020; Disetujui:14 Agustus 2020

*Email: manihurukpronika@gmail.com

\begin{abstract}
Abstrak
Tindak pidanapencucian uang marak terjadinya di Indonesia dengan bank sebagai sarananya. Kelamahan-kelemahan yang terdapat dalam sistem perbankan menjadi celah bagi pelaku pencucian uang untuk melakukanperbuatannya sehingga hasil kejahatan yang diperolehnya aman disimpan di bank. Penelitian ini merupakan penelitian hukum normatif yang bersifat deskriptif analisis, dengan pendekatan perundang-undangan dan konseptual dengan pendekatan kasus. Tujuan penulisan ini untuk menganalisis peran perbankan dalam upaya pencegahan dan pemberantasan tindak pidana pencucian uang yang dilakukan nasabah dalam perspektif undang-undang perbankan dan modus yang dilakukan oleh pelaku tindak pidana pencucian uang di bank. Hasil penelitian ini menunjukkan bahwa modus yang dilakukan oleh pelaku tindak pidana pencucian uang dalam melakukan pencucian uang di bank adalah melalui kerja sama modal melalui agunan kredit, tranfer ke luar negeri, penyamaran usaha di dalam negeri, rekayasa pinjaman luar negeri dan peran perbankan dalam upaya pencegahan dan pemberantasan tindak pidana pencucian uang dan undang-undang perbankan adalah dengan cara mengenali calon nasabah yang akan membuka rekening di bank seta memantau profil dan transaksi nasabah yang dilakukan secara berkesinambungan, meliputi kesesuaian antara profil transaksi dengan profil nasabah, meneliti kemiripan atau kesamaan nama dengan nama tersangka/terdakwa yang dipublikasikan dalam media massa atau oleh otoritas yang berwenang.
\end{abstract}

Kata Kunci: Peran, Perbankan, Pemberantasan, Pencucian Uang

\begin{abstract}
Money laundering is rampant in Indonesia with banks as a means. Weaknesses in the banking system provide a loophole for money launderers to carry out their actions so that the proceeds of crime obtained are safely stored in banks. This research is a normative legal research that is descriptive in nature, with a case appoach. The purpose of this paper is to analyze the role of banks in effors to prevent and eradicate money laundering crimes committed by customers in the perspective of banking laws and the mode of action committed by money laundering criminals in banks. The results of this study indicate that themode of conduct of money laundering in conducting money laundering in banks is through capital cooperation though credit collateral, overseas transfers, disguising domestic businessses, engineering foreign loans and the role of banks in preventing and eradicating money laundering and banking laws by recognizing prospective customers who will open accounts in banks and monitoring customer profiles and transactions carried out on an on going basis, including conformity between transaction profile, examining the similarity or similarity of names with names suspects/defendants published in the mass media or by the competent authority.
\end{abstract}

Keywords: Role, Banking, Eradication, Money Laundering

How to Cite: Manihuruk, P.J. Eddy, T. \& Fauzi, A. (2020). Peran Perbankan Dalam Pencegahan Dan Pemberantasan Tindak Pidana Pencucian Uang OlehNasabah. Journal of Education, Humaniora and Social Sciences (JEHSS). 3(2): 325-332. 


\section{PENDAHULUAN}

Mewujudkan kesejahteraan rakyat sebagaimana termaktub dalam pembukaan undangundang dasar negara republik Indonesia tahun 1945 merupakan cita-cita negara republik Indonesia. Implikasi dari adanya cita-cita negara adalah penyelenggara baik dari aspek politik, ekonomi, sosial, maupun budaya yang diupayakan untuk mewujudkan cita-cita, penyelenggara negara haruslah berdasarkan kepada pancasila sebagai dasar negara. Cita-cita mewujudkan kesejahteraan rakyat tersebut bukanlah sesuatu yang mudah untuk dilakukan. Lebih dari 70 tahun Indonesia merdeka, hingga hari ini konsep kesejahteraan itu masih sulit untuk diwujudkan. Kesejahteraan dalam pendangan masyarakat awam itu domainnya adalah dalam bidang ekonomi rakyat secara nyata. Seiring dengan berjalannya waktu, pesatnya pertumbuhan ekonomi dunia yang mengarah kepada era globlisasi telah memberikan peluang akan tumbuhnya perusahaan-perusahaan transnasional untuk memainkan perananya. Peran korporasi tersebut sering dirasakan bahkan banyak mempengaruhi sektor-sektor kehidupan masyarakat. Dampak yang dirasakan tersebut dapat bersifat positif dan negatif, namun dampak yang bersifat negatif yang lebih sering terjadi dan dirasakan. (Mulyadi \& Surbakti, 2010)

Semakin berkembang teknologi, maka semakin berkembang pula jenis-jenis kejahatan. Dahulunya hanya dikenal kejahatan tradisional seperti pencurian, pembunuhan dan lainnya yang telah dikriminalisasi dengan berlakunya kitab undang-undang hukum pidana (KUHP). Tapi sekarang dikenal sebuah fenomena kejahatan baru, seperti tindak pidana korupsi, perdagangan narkotika dan psikotropika, penyuapan, dan terorisme. Missalanya saja tindak pidana korupsi, kejahatan yang dilakukan oleh pejabat negara yang mempunyai jabatan pemerintahan ini sering disebut dengan kejahatan kerah putih (white collar crime). Kejahatan yang ahanya dilakukan oleh orang-orang berdasi. Para koruptor mencuri uang negara hingga miliyaran atau bahkan triliunan rupiah, uang yang tidak sedikit bila digunakan untuk bantuan sarana pendidikan, kesehatan dan perluasan lapangan pekerjaan (Rachman, 2010). Para koruptor, teroris, serta kejahatan kerah putih lainnya yang memiliki uang serta aset yang jumlahnya fantastik, sering kali menyimpan uang hasil kejahatan dengan cara money laundring (pencucian uang) di berbagai lembaga keuangan sehingga hasil kejahatan itu tidak terlacak oleh aparat keamanan. Hal itu dilakukan agar aset dan uang yang tersebut, dapat digunakan untuk kebutuhan hidup dalam jangka waktu yang panjang.

Berkembangnya ilmu pengetahuan dan teknologi berbanding lurus dengan perkembangan praktik dan bentuk-bentuk tidak kejahatan, seperti berkembangnya tindak pidana pencucian uang seiring dengan pekembangan dalam dunia bisnis yang ditopang oleh perkembangan teknologi sebagain sebuah tindak pidana kerah putih. Bila dilihat secara sepintas, TTPU seolaholah sebagai sebuah tindakan yang tidak ada korbannya, TPPU tindak seperti tindak kejahatan lain seperti pembunuhan, narkotika yang menyisakan korban secara nyata. TTPU gilirannya akan yang akan sangat berdampak kepada sektor perekonomian dan bisnis dengan membawa dampak buruk yang cukup[ signifikan (Hakim, 2015).

\section{METODE PENELITIAN}

Penelitian ini menggunakan penelitian hukum normatif, dengan pendekatan penelitian terhadap asas-asas hukum, penelitian hukum hukum in concreto, penelitian singkronisasi hukum, penelitian sistem hukum dan perbandingan hukum. (Ronny, 1990). Penelitian hukum normatif disebut juga penelitian hukum normatif dengan dua pendekatan perundang-undangan yaitu pendekatan terhadap produk-produk hukum dimana penelitian ini mengkaji dan meneliti mengenai produk-produk hukum. Pendekatan konseptual yaitu pendekatan yang digunakan terhadap konsep-konsep hukum antara lainlembaga hukum, fungsi hukum dan sumber hukum. (Johnny, 2005) Sifat penelitian ini deskriptif analisis yaitu penelitian yang menggambarkan objek, menerangkan dan menjelasakan sebuah peristiwa dengan maksud untuk mengetahui keadan objek yang diteliti. 


\section{HASIL DAN PEMBAHASAN \\ Modus Yang Dilakukan Oleh Pelaku Tindak Pidana Pencucian Uang}

Pencucian uang dalam bahasa Inggris disebut dengan money laundering. Terminologi money laundering sebenarnya belum lama dipakai. Istilah ini pertama kali dipakai oleh surat kabar dalam memberitakan skandal Watergate yang melibatkan Presiden Richard Nixon pada tahun 1973 (Yani, 2013). Adrian Sutedi mengatakan bahwa pencucian uang adalah suatu proses atau perbuatan yang bertujuan untuk menyembunyikan atau menyamarkan asal-usul uang atau harta kekayaan yang diperoleh dari hasil tindak pidana yang kemudian diubah menjadi harta kekayaan yang seolah-olah berasal dari kegiatan yang sah (Sutedi, 2007) Saat ini pencucian uang atau money laundering sudah merupakan fenomena dan menjaditantangan dalam dunia internasional. (Goverment, 2000) Semua negara di dunia sepakat bahwa pencucian uang merupakan suatu tindak kejahatan yang harus dihadapi dan diberantas. Pihak penuntut dan lembaga penyidikan kejahatan, kalangan pengusaha dan perusahaan, negara-negara yang telah maju dan negara-negara dunia ketiga, masing-masing mempunyai definisi sendiri berdasarkan skala prioritas dan perspektif yang berbeda (Sjahdeini, 2003).

Modus yang digunakan oleh pelaku kejahatan pencucian uang ada berbagai macam, dengan kecerdasan dan kemajuan teknologi pada umumnya dilakukan dengan melakukan kerja sama modal dalam modus ini membawa membawa uang secara tunai dari hasil kejahatan tersebut ke luar negeri, kemudian dimasukkan kembali kedalam negeri dengan cara menginvestasikan melalui proyek-proyek penanaman modal asing (joint venture project). Keuntungan dari proyek tersebut sudah menjadi bersih karena tampak secara legal dan bisa di nikmati, bahkan sudah dikenakan pajak. Melalui agunan kredit menyelundupkan uang hasil dari kejahatan tersebut ke luar negeri terlebih dahulu dengan menyimpan di bank-bank tertentu.Dari salah satu bank tersebut, uang tersebut ditransfer ke bank Swiss dalam bentuk deposito. Kemudian operandi melakukan pinjaman ke suatu bank di Eropa dengan menggunakan jaminan deposito tersebut. Uang dari pinjaman tersebut dikembalikan/ ditanamkan kembali ke Negara asal uang tersebut didapatkan, karena sudah menjadi uang bersih. Transfer keluar negreri uang tunai yang dibawa oleh operandi ditransfer ke luar negeri melalui bank asing yang bercabang di Negara asalny. Kemudian uang tersebut dicairkan dan dibawa oleh orang-orang tertentu kembali ke Negara asalnya, sehingga tampak uang tersebut didapat dari luar negeri. Penyamaran usaha di dalam negeri Uang tersebut digunakan untuk mendirikan perusahaan bisnis samaran di dalam negeri.Operandi tidak mempermasalahkan uang tersebut mengalami keuntungan atau kegurian, karena uang tersebut tampak bahwa perusahaan bisnisnya menghasilkan uang bersih (clean money).

Penyamaran dalam perjudian selain mendirikan perusahaan bisnis, biasanya perusahaan perjudian menjadi pilihan operandi untuk menyamarkan kekayaannya dengan membeli nomor undian yang telah dipesan dengan harga tertinggi dan nomor tersebut keluar sebagai pemenang, sehingga tampak bahwa uang/harta itu berasal dari usaha tersebut. Penyamaran dokumen secara fisik uang tersebut tidak kemana-mana melainkan tetap ditempat yaitu didalam negeri.Keberadaan uang tersebut dilengkapi dengan dokumen-dokumen bisnis double invoice dalam bisnis ekspor-impor dari perusahaan yang dipalsukan atau direkayasa sehingga uang tersebut seolah-olah berasal dari bisnis ekspor-impor tersebut. Pinjaman luar negeri Uang hasil kehatatan ini secara tunai dibawa ke luar negeri.Kemudian dimasukkan kembali ke dalam negeri dalam bentuk pinjaman luar negeri, seolah-oleh uang tersebut diperoleh karena pinjaman (bantuan kredit) luar negeri. Rekayasan pinjamana luar negeri uang tersebut tidak kemana-mana melainkan ada di dalam negeri.Kemudian operandi membuat dokumen rekayasa/palsu seakanakan mendapat bantuan atau pinjaman dari luar negeri (Sutedi, 2008)

Berdasarkan modus, teknik pencucian uang serta metodenya, maka tidak salah jika pencucian uang memang membahayakan bagi kehidupan ekonomi sebuah negara. Pencucian uang sudah menjadi sebuah kejahatan bisnis yang tidak hanya terjadi dalam lembaga keuangan, apakah itu perbankan maupun lembaga keuangan non bank dalam lingkup kecil saja ataupun dimungkinkan dilakukan oleh perorangan maupun korporasi melalui lintas negara (cross border) 
atau tanpa batas tertentu lagi. Hal ini yang menyebabkan betapa sulitnya bagi negaranegara untuk dilakukan pemeberantasan terhadap hasil kejahatan pencucian uang ini secara optimal. Secara umum ada beberapa alasan mengapa money laundering diperangi dan dinyatakan sebagai tindak pidana, yaitu: pengaruh money laundering pada sistem keuangan dan ekonomi diyakini berdampak negatif bagi perekonomian dunia.

Fluktuasi yang tajam pada nilai tukar dan suku bunga merupakan bagian dari akibat negatif dari pencucian uang. Dengan adanya berbagai dampak negatif itu diyakini, bahwa money laundering dapat mempengaruhi perekonomian dunia. Dinyatakan money laundering sebagai tindak pidana akan lebih memudahkan bagi aparat hukum untuk menyita hasil tindak pidana yang kadangkala sulit untuk disita, misalnya aset yang susah dilacak atau sudah dipindahtangankan kepada pihak ketiga. Dengan ini, maka pemberantasan tindak pidana sudah beralih orientasinya dari "menindak pelakunya" ke arah menyita "hasil tindak pidana Dinyatakan money laundering sebagai tindak pidana dan dengan adanya sistem pelaporan transaksi dalam jumlah tertentu dan transaksi yang mencurigakan, maka hal ini lebih memudahkan bagi para penegak hukum untuk menyelidiki kasus pidana sampai kepada tokok-tokoh yang ada di belakangnya.

Karena pengaruh money laundering pada sistim keuangan dan ekonomi diyakini berdampak negatif bagi perekonomian dunia, misalnya dampak negatif terhadap efektifitas penggunaan sumber daya dan dana. Dengan adanya money laundering sumber daya dan dana banyak digunakan untuk kegiatan yang tidak sah dan dapat merugikan masyarakat, disamping itu dana-dana banyak yang kurang dimanfaatkan secara optimal, misalnya dengan melakukan "sterile investment" dalam bentuk property atau perhiasan yang mahal Hal ini terjadi karena uang hasil tindak pidana terutama diinvestasikan pada negara-negara yang dirasakan. ditetapkannya money laundering sebagai tindak pidana akan lebih memudahkan bagi aparatur penegak hukum untuk menyita hasil tindak pidana yang kadangkala sulit untuk disita, misalnya aset yang susah dilacak atau sudah dipindahtangankan kepada pihak ketiga. Dengan cara ini pelarian uang hasil tindak pidana dapat dicegah. Dengan demikian pemberantasan tindak pidana sudah beralih orientasinya dari "menindak pelakunya" ke arah menyita "hasil tindak pidana". Di banyak negara dengan menyatakan money laundering sebagai tindak pidana merupakan dasar bagi penegak hukum untuk mempidanakan pihak ketiga yang dianggap menghambat upaya penegakan hukum.

Dinyatakan money laundering sebagai tindak pidana dan dengan adanya sistem pelaporan transaksi dalam jumlah tertentu dan transaksi yang mencurigakan, maka hal ini lebih memudahkan bagi para penegak hukum untuk menyelidiki kasus pidana sampai kepada tokohtokoh yang ada dibelakangnya. Tokoh-tokoh ini sulit dilacak dan ditangkap karena pada umumnya mereka tidak kelihatan pada pelaksanaan suatu tindak pidana, tetapi banyak menikmati hasil-hasil tindak pidana tersebut (Stessen, 2002) Banyaknya modus yang dapat dilakukan oleh para pelaku tindak pidana pencucian uang seharusnya dapat diantisipasi oleh pihak perbankan sesuai dengan peran yang telah ada pada lembaga perbankan tersebut. Peran yang diemban oleh perbankan dalam mencegah terjadinya tindak pidana pencucian yang dilakukan oleh nasabah tidaklah telalu berat. Hal ini disebabkan peran perbankan dalam mencegah tindak pidana pencucian uang karena ada Pusat Penelitian dan Analisis Transaksi Keuangan (PPATK) dan Otoritas Jasa Keuangan (OJK) sebagai mitra kerjasama yang dapat membantu dalam upaya pengungkapan tindak pidana pencucian uang.

\section{Peran Perbankan dalam Upaya Pencegahan dan Pemberantasan Tindak Pidana Pencucian Uang yang Dilakukan Nasabah dalam Perspektif Undang-Undang Tindak Pidana Pencucian Uang dan Undang-Undang Perbankan}

Bank adalah suatu lembaga keuangan yang eksistensinya tergantung mutlak pada kepercayaan dari para nasabahnya yang mempercayakan dana dan jasa-jasa lain yang dilakukan mereka melalui bank pada khususnya dan dari masyarakat luas pada umumnya. Oleh karena itu, bank sangat berkepentingan agar kadar kepercayaan masyarakat, yang sudah mampu yang akan menyimpan dananya, maupun yang telah atau akan menggunakan jasa-jasa bank lainnya 
terpelihara dengan baik dalam tingkat yang lebih tinggi. Mengingat bank adalah bagian dari sistem keuangan dan sistem pembayaran, masyarakat luas berkepentingan atas kesehatan dari system-sistem tersebut. Adapun kepercayaan masyarakat kepada bank merupakan unsur paling pokok dari eksistensi suatu bank sehingga terpeliharanya kepercayaan masyarakat kepada perbankan adalah juga kepentingan masyarakat banyak (Sutedi, 2010).

Pemanfaatan lembaga keuangan dalam kejahatan pencucian uang dapat berupa menginvestasikan dan memindahkan uang dari hasil tindak pidana seperti uang hasil korupsi, suap, penipuan, kejahatan di bidang perbankan, pasar modal dan lainnya ke dalam bentuk deposito, pembelian traveler cheque, saham, obligasi, reksadana dan instrument keuangan lainnya. Money laundering atau pencucian uang pada intinya melibatkan asset (pendapatan atau kekayaan) yang disamarkan sehingga dapat dipergunakan tanpa terdeteksi bahwa aset tersebut berasal dari kehajatan yang illegal. Melalui Money Laundering pendapatan atau kekayaan yang berasal dari kegiatan yang melawan hokum diubah menjadi aset keuangan yang seolah-olah berasal dari sumber yang sah atau legal (Fuady, 2001)

Kegiatan money laundering dalam sistem keuangan pada umumnya dan sistem perbankan pada khususnya memiliki risiko yang sangat besar. Risiko tersebut antara lain risiko operasional, risiko hukum, risiko terkonsentrasinya transaksi, dan risiko reputasi. Bagi perbankan Indonesia tindakan pencucian uang merupakan suatu hal yang sangat rawan karena pertama, peranan sektor perbankan dalam sistem keuangan di Indonesia seperti yang dijelaskan sebelumnya, sangatlah penting. Oleh sebab itu sistem perbankanmenjadi perhatian utama dalam pelaksanaan rezim anti money laundering. Kedua, tingginya tingkat perkembangan teknologi dan arus globalisasi di sektor perbankan membuat industri perbankan menjadi lahan yang empuk bagi tindak kejahatan pencucian uang dan merupakan sarana yang paling efektif untuk melakukan kegiatan money laundering. Pelaku kejahatan dapat memanfaatkan bank untuk kegiatan pencucian uang karena jasa dan produk perbankan memungkinkan terjadinya lalu lintas atau perpindahan dana dari satu bank ke bank atau lembaga keuangan lainnya, sehingga asal usul uang tersebut sulit dilacak oleh penegak hukum.

Keterlibatan perbankan dalam kegiatan pencucian uang dapat berupa, Penyimpanan uang hasil kejahatan dengan nama palsu, Penyimpanan uang dalam bentuk deposito/tabungan/ giro, Penukaran pecahan uang hasil perbuatan illegal, Pengajuan permohonan kredit dengan jaminan uang yang disimpan pada bank yang bersangkutan, Penggunaan fasilitas transfer; Pemalsuan dokumen-dokumen yang bekerjasama dengan oknum pejabat bank terkait; dan pendirian/pemanfaatan bank gelap (Raihan, 2015).

Hal tersebut dapat terjadi mengingat adanya kemudahan dalam proses pengelolaan hasil kejahatan pada berbagai kegiatan usaha bank. Disamping itu, karena organisasi kejahatan membutuhkan pengelolaan keuangan dengan cara menempatkan dananya dalam kegiatan usaha perbankan maka penggunaan bank merupakan suatu hal yang sangat diperlukan dalam upaya mengaburkan asal-usul sumber dana. Hal tersebut menunjukkan eratnya keterkaitan antara organisasi kejahatan dan lembaga keuangan terutama bank. Kejahatan ini relatif memang masih baru dikenal, sehingga penyelidikannya pun masih sulit dilakukan karena memerlukan keahlian khusus serta keuletan dan ketelitian. Kejahatan teknologi di suatu pihak membawa pengaruh positif dalam berbagai bidang, namun di sisi lain dapat mengakibatkan semakin meningkatnya kualitas kejahatan dengan mempergunakan cara-cara dan sarana kejahatan yang semakin canggih pula berupa kejahatan intelektual seperti penipuan milyaran dan korupsi skala besar yang tidak kelihatan (Pardede, 1995).

Penanggulangan tindak pidana pencucian uang yang telah dijelaskan di atas bahwa tindak pidana pencucian uang tersebut dapat terjadi di Bank. Di dalam bank apabila terjadi transaksi yang mencurigakan terhadap nasabahnya dalam melakukan transaksi, maka pihak bank akan segera melaporkan ke PPATK agar PPATK yang akan menanganinya secara langsung. Di bank ada dua macam transaksi yang harus di laporkan kepada PPATK yaitu pertama, transaksi tunai, dimana nasabahnya akan dicurigai apabila nasabahnya melakukan transaksi Rp.500.000.000,00 (Lima ratus juta rupiah) ke atas, baik dalam negeri maupun luar negeri seperti yang terdapat 
didalam Pasal 23 ayat 1 (b) Undang-Undang No.8 Tahun 2010. Kedua transaksi mencurigakan, dimana pihak bank akan mencurigai setiap transaksi yang dilakukan oleh nasabahnya, apabila lewat dari transaksi yang biasa dilakukan oleh nasabahnya. Dan akan langsung dilaporkan kepada Pusat Pelapor dan Analisis Transaksi Keuangan (PPATK). Karena pada saat melakukan transaksi maka bank akan melihat data-data dari profil calon nasabahnya. Agar bank tidak dijadikan media tempat terjadi tindak pidana pencucian uang. (Nugroho:2016). Dengan demikian, pihak bank dalam hal ini harus mengenali nasabahnya terlebih dahulu agar terhindar dari praktik pencucian uang yang dilakukan oleh nasabah.

Menurut Pasal 18 ayat 3 Undang-Undang Nomor 8 Tahun 2010 kewajiban menerapkan prinsip mengenali pengguna jasa harus dilakukan pada saat:

1. Melakukan hubungan usaha dengan pengguna jasa;

2. Terdapat transaksi keuangan dengan mata uang asing yang nilainya paling sedikit atau setara dengan Rp 100.000.000,00 (seratus juta rupiah);

3. Terdapat transaksi keuangan mencurigakan yang terkait tindak pidana pencucian uang dan tindak pidana pendanaan terorisme; atau

4. Pihak pelapor meragukan kebenaran informasi yang dilaporkan pengguna jasa.

Ada beberapa ketentuan umum prinsip mengenali pengguna jasa menurut Undang-Undang Nomor 8 Tahun 2010 yaitu:

1. Identifikasi Pengguna Jasa, Ada beberapa hal yang perlu diperhatikan dalam melakukan identifikasi pengguna jasa keuangan yaitu:

a) Jika melakukan hubungan usaha, setiap orang wajib memberikan identitas lengkap kepada Penyedia Jasa Keuangan;

b) Setiap orang yang melakukan transaksi dengan pihak pelapor wajib memberikan identitas dan informasi yang benar yang dibutuhkan oleh pihak pelapor dan sekurangkurangnya memuat identitas diri, sumber dana, dan tujuan transaksi dengan mengisi formulir yang diperhatikan oleh pihak pelapor dan melampirkan dokumen pendukungnya;

c) Dalam hal transaksi dilakukan untuk kepentingan pihak lain, setiap orang wajib memberikan informasi mengenai identitas diri, sumber dana, dan tujuan transaksi pihak lain tersebut;

d) Penyedia jasa keuangan wajib memastikan pengguna jasa bertindak untuk siapa;

e) Pihak pelapor wajib mengetahui bahwa pengguna jasa yang melakukan transaksi dengan pihak pelapor bertindak untuk diri sendiri atau untuk dan atas nama orang lain;

f) Dalam hal transaksi dengan pihak pelapor dilakukan untuk diri sendiri atau untuk dan atas nama orang lain, pihak pelapor wajib meminta informasi mengenai identitas dan dokumen pendukung dari pengguna jasa dan orang lain terebut;

g) Dalam hal identitas dan/atau dokumen pendukung yang diberika tidak lengkap, pihak pelapor wajib menolak transaksi dengan orang tersebut;

h) Penyedia jasa keuangan wajib menyimpan catatan dan dokumen;

i) Pihak pelapor wajib menyimpan catatan dan dokumen mengenai identitas pelaku transaksi paling singkat 5 (lima) tahun sejak berakhirnya hubungan usaha dengan pengguna jasa tersebut.

2. Verifikasi Pengguna Jasa

a) Identitas dan dokumen pendukung yang diminta oleh pihak pelapor harus sesuai dengan ketentuan peraturan perundang-undangan yang ditetapkan oleh setiap lembaga pengawas dan pengatur;

b) Penyedia jasa keuangan harus memperoleh keyakinan mengenai identitas nasabah baik perorangan maupun perusahaan, apabila nasabah bertindak untuk dan atas nama pihak lain maka identitas pihak lain tersebut juga wajib diminta dan diverifikasi

c) Prosedur pembuktian identitas nasabah berlaku sama untuk setiap produk yang dikeluarkan oleh penyedia jasa keuangan dan penyedia jasa keuangan harus memiliki salinan dokumen tersebut dan menatausahakannya dengan baik; 
d) Penyedia jasa keuangan wajib memutuskan hubungan usaha dengan pengguna jasa apabila pengguna jasa menolak untuk mematuhi prinsip mengenali pengguna jasa dan penyedia jasa keuangan meragukan kebenaran informasi yang disampaikan oleh pengguna jasa;

e) Penyedia jasa keuangan wajib melaporkannya kepada PPATK mengenai tindakan pemutusan hubungan usaha tersebut sebagai transaksi keuangan mencurigakan.

\section{SIMPULAN}

Bahwa modus yang dilakukan oleh pelaku tindak pidana pencucian uang dalam melakukan pencucian uang di bank adalah melalui kerjasama modal; melalui agunan kredit;transfer ke luar negeri; penyamaran usaha di dalam negeri; penyamaran dalam perjudian; penyamaran dokumen;pinjaman luar negeri;rekayasa pinjaman luar negeri. Bahwa peran perbankan dalam upaya pencegahan dan pemberantasan tindak pidana pencucian uang yang dilakukan nasabah dalam perspektif Undang-Undang Tindak Pidana Pencucian Uang dan Undang-Undang Perbankan adalah dengan cara mengenali calon nasabah yang akan membuka rekening di suatu bank serta pemantauan profil dan transaksi nasabah yang dilakukan secara berkesinambungan meliputi kegiatan memastikan kelengkapan informasi dan dokumen nasabah; meneliti kesesuaian antara profil transaksi dengan profil nasabah; meneliti kemiripan atau kesamaan nama dengan nama yang tercantum dalam database; meneliti kemiripan atau kesamaan nama dengan nama tersangka atau terdakwa yang dipublikasikan dalam media massa atau oleh otoritas yang berwenang.

\section{DAFTAR PUSTAKA}

Dirham, R. (2015), “Tindak Pidana Pencucian Uang (Money Laundering) Dalam Transaksi Perbankan". Karya Ilmiah. Fakultas Hukum Universitas Hasanuddin.

Fuady, M. (2001), Hukum Perbankan Modern Buku Kedua (Tingkat Advance),Bandung: PT. Citra Aditya Bakti,

Goverment, US. (2000), Secretary of Treasury and Attorney General, The National Money Laundering Strategy 2000.

Hakim, A.L. \& Martin, A.Y., (2015). “Tindak Pidana Pencucian Uang Dan Modusnya Dalam Perspektif Hukum Bisnis", dalam Jurnal De'Rechstaat, Volume I, Nomor 1

Husein, Y. (2002). "Upaya Penanganan Tindak Pidana Pencucian Uang (Money Laundering)," makalah disampaikan pada Seminar Nasional Mengenai Tindak Pidana Pencucian Uang, iselenggarakan oleh Universitas Sumatera Utara (USU), Medan, tanggal 30 Oktober 2002.

Ibrahim, J. (2005), Teori dan Metodologi Penelitian Hukum Normatif, Malang: Bayumedia.

Mulyadi, M. dan Surbakti, F.A. (2010), Politik Hukum Pidana Terhadap Kejahatan Korporasi, Cetakan Pertama, Jakarta: PT. Sofmedia.

Nugroho, N. (2016), “Analisis Terhadap Pencegahan Tindak Pidana Pencucian Uang Oleh Bank BNI Di Tinjau Dari Undang Undang Nomor 8 Tahun 2010 Tentang TPPU", dalam Jurnal Mercatoria,Volume 9, Nomor 2, Desember,

Pardede, M. (1995), Hukum Pidana Bank, Jakarta : Pustaka Sinar Harapan,

Rachman, M.R. (2019) "Permasalahan Tindak Pidana Asal (Predicate Offence) Dalam Upaya Pencegahan Dan Pemberantasan Tindak Pidana Pencucian Uang (Money Laundering)", dalam https://academia.edu., diakses tanggal 1 September 2019.

Sjahdeini, S.R. (2003), "Pencucian Uang: Sejarah, Faktor Penyebab, dan Dampaknya Bagi Masyarakat", dalam Jurnal Hukum Bisnis, Volume 22, Nomor 3, Tahun

Soemitro, R.H. (1990), Metode Penelitian Hukum dan Jurimetri, Jakarta: Ghalia Indonesia, Cetakan Keempat.

Sutedi, A, (2007), Hukum Perbankan: Suatu Tinjauan Pencucian Uang, Merger, Likuidasi, Dan Kepailitan, Jakarta: Sinar Grafika, hlm. 19. Lihat juga Iman Sjahputra, 2006, Money Laundering (Suatu Pengantar), Jakarta: Harvindo.

Sutedi, A. (2008), Tindak Pidana Pencucian Uang, Bandung: PT Citra Aditya Bakti. 
Pronika Juliantika Manihuruk, Triono Eddy \& Ahmad Fauzi, Peran Perbankan Dalam Pencegahan Dan

Sutedi, A. (2010), Hukum Perbankan Suatu Tinjauan Pencucian Uang, Marger, Likuidasi ,dan Kepailitan, Jakarta : Sinar Grafika.

Yani, M.A. (2013), “Kejahatan Pencucian Uang (Money Laundering) (Tinjauan Undang-Undang Nomor 8 Tahun 2010 Tentang Pencegahan Dan Pemberantasan Tindak Pidana Pencucian Uang”, dalam EJournal WIDYA Yustisia, Volume 1 Nomor 1 Mei-Agustus. 